\title{
Mechanic and Ennerory
}

http://dx.doi.org/10.1590/0370-44672015700189

\author{
Washington Luís Vieira Silva \\ Professor \\ Universidade Federal de Ouro Preto - UFOP \\ Escola de Minas \\ Departamento de Engenharia de Controle e \\ Automação e Técnicas Fundamentais \\ Ouro Preto - Minas Gerais - Brasil \\ wlvsilva@hotmail.com
}

\section{Leonardo Carvalho Oliveira Souza Professor \\ Universidade Federal de Ouro Preto - UFOP Escola de Minas \\ Departamento de Engenharia de Controle e Automação e Técnicas Fundamentais \\ Ouro Preto - Minas Gerais - Brasil \\ leocarvalhobh@gmail.com \\ Luís Antônio Bortolaia \\ Professor \\ Universidade Federal de Ouro Preto - UFOP Escola de Minas \\ Departamento de Engenharia de Controle e Automação e Técnicas Fundamentais \\ Ouro Preto - Minas Gerais - Brasil \\ luis.bortolaia@em.ufop.br}

\section{Milton Realino de Paula}

\section{Professor}

Universidade Federal de Ouro Preto - UFOP

\section{Escola de Minas}

Departamento de Engenharia de Controle e Automação e Técnicas Fundamentais

Ouro Preto - Minas Gerais - Brasil

realino@em.ufop.br

\section{Elisângela Martins Leal}

\section{Professora}

Universidade Federal de Ouro Preto - UFOP Escola de Minas

Departamento de Engenharia de Controle e Automação e Técnicas Fundamentais

Ouro Preto - Minas Gerais - Brasil

elisangelamleal@decat.em.ufop.br

\section{Study of the electricity consumption reduction of a compressed air system: the case of a steelmaking company}

\begin{abstract}
This work aims to reduce the energy consumption and thus increase the availability of blast furnace compressors of a steelmaking company, located in Alto Paraopeba region in Minas Gerais state, Brazil, through the elimination of waste points in the compressed air distribution. In order to develop this work, an ultrasound test in the compressed air line was performed to identify and quantify leaks in the flow. Once the leaks were identified, they were eliminated through corrective maintenance and improvements, and then the energy consumption scenarios before and after the improvements were compared. As a result, the average monthly electricity consumption in the reporting period decreased by $57.2 \%$. In addition, one compressor was set aside in stand-by condition, as in the original plant. Thus, one can prove the efficiency in eliminating of waste points in compressed air distribution, since the reduction of energy consumption is important for the company to remain competitive, as the cost of electric energy affects the final price of the final products.
\end{abstract}

keywords: compressed air, compressor, energy efficiency, ultrasound test, leaks. 


\section{Introduction}

Humankind has been using compressed air since its existence for the simple act of blowing a brazier to light a flame. Lungs may be considered compressors, since they are able to process $100 \mathrm{~L} / \mathrm{min}$ or $6 \mathrm{~m}^{3} / \mathrm{h}$ of air, using a pressure from 0.02 to $0.08 \mathrm{bar}$ (Atlas Copco, 1976). Through this simple example, the importance of the compressed air use to humanity is demonstrated.

Currently, compressed air deliveries power to a wide variety of industrial operations, comprising of small plants to heavy industry, being used in virtually all stages of production.

A generic pneumatic system can be divided into three parts: generation, distribution and end use. Rocha and Monteiro (2005) characterized each one as: (i) generation unit includes the compressor driven by an electrical motor (which captures the gas and increases its pressure), automation and control, air handling equipment, tank and accessories; (ii) distribution unit takes the compressed air from the reservoirs to the end use, ensuring that this air reaches the optimal quantity and pressure free of water and impurities; (iii) at the end use unit, the application is varied, for example, to drive pneumatic tools and camshafts.

Electrical energy is consumed for the generation of compressed air. According to Rocha and Monteiro (2005), compressed air is one of the most expensive energy forms in an industrial plant, with the largest expenditures in electricity consumption, which may represent $30 \%$ or more of the total electricity consumed.

Thus, with the increasing market competitiveness, companies have continually sought to reduce operating costs to keep their products at competitive prices, ensuring the satisfaction of their customers and shareholders. It is important, therefore, to make conscious compressed air consumption in order to avoid unnecessary costs.

According to Beyene apud Raduenz et al. (2009), the main cause of waste in pneumatic systems is leaks. Rocha and Monteiro (2005) state that these leaks can represent in industrial compressed air systems without maintenance, 10 to $40 \%$ of the maximum compressed air demand, being the admitted value for losses of up to $10 \%$ for steelmaking industries (Macintyre, 1996).

In order to avoid the compressed air depletion through leaks, the maintenance of all compressed air distribution is necessary. According to Xenos (2004), maintenance activities prevent degradation of equipment and facilities caused by their use, wear and tear. This fact generates losses of performance and production downtime, besides of the manufacture of poor quality products and environmental pollution.

One of the biggest uses of compressed air in industry is the manufacture of iron and steel. It takes approximately 3,000 cubic meters of compressed air to produce 1 ton of steel. Rollins (2004) highlights some applications for compressed air: "Compressed air is used in the iron and steel industry for many purposes in addition to the basic process, mainly as a drive force from the functional equipment and tool. These applications include deburring and grinding ingots, trigger hoists and lifts, shake solutions, blast and caulk tanks. They also include the operation of machines to punch, carvings, oven doors, instrumentation and process control, dumper ingots, drive bell of a blast furnace and coke gates, lubrication systems, clutches and pneumatic brakes, mixing materials, descaling, pneumatic clamps, etc.

In this context, the compressed air system of a steelmaking company is studied. The steelmaking plant has 169 air, argon and nitrogen compressors. The compressors are from Ingersoll Rand, Atlas Copco, Chicago, Sullair, and Worthington and Wayne, all driven by electric motors, with power ranging from 5 to $500 \mathrm{~kW}$. Because of the plant size, several compressed air centrals are located in each production area, among them the blast furnace one.

According to the company (2013), the blast furnace production area is responsible for delivering molten metal, having an installed production capacity of 1.5 million of tons per year. It has three compressors from Atlas Copco; model GA315W with rated power of 271 $\mathrm{kW}$. Each compressor at full load is able to deliver about $2790 \mathrm{~m}^{3} / \mathrm{h}$ of compressed air with an average pressure of 7.4 bar $(7400 \mathrm{kPa})$ for the production process.

The target area of the study has three compressors; one should work full time, the other one as charge and relief, and the last one as stand-by, only triggered in the event of temporary need. This was the initial plan for the area. However, in practice, one compressor works full time and the other two compressors works in charge and relief to meet the demand. Taking the question of availability into account, in case of stopping one of the ma- chines for maintenance, the compressed air delivery is compromised. In parallel, the overloaded operation of the system raises the costs of electricity, raising the production costs of the company. Thus, the study aims to reduce the final energy consumption of the blast furnace plant compressors and to return the compressor to optimal working condition, according to the initial design of the plant.

According to Gonçalves and Cardoso apud Junior and Peixoto (2010), energy is the biggest expense in compressed air systems, accounting for $73 \%$ of total expenditure, which confirms the importance of energy efficiency of these systems.

Rollins (2004) alleged that valves, records and joints lose a considerable amount of compressed air, which when added up may total a huge amount of losses. In addition to leaks in the distribution accessories, holes in the pipe must be considered. Atlas Copco (1976) and Rock and Miller (2005) stated that for a working pressure of 6 bar $(600 \mathrm{kPa})$, the power required to supply the lost compression on a $1 \mathrm{~mm}$ hole is $0.3 \mathrm{~kW}$, for $3 \mathrm{~mm}$ hole is $3.1 \mathrm{~kW}$, and for $15 \mathrm{~mm}$ hole is $132 \mathrm{~kW}$, which shows an exponential growth in electrical power.

To illustrate the losses in financial terms, a hole of $10 \mathrm{~mm}$ of diameter, slipping $6.3 \mathrm{~m}^{3} / \mathrm{min}$ of compressed air at 6 bar for 24 hours, in a year generates an approximate additional expenditure of R\$ 49,100.00 (about US\$ 19,640.00, considering $2.5 \mathrm{R} \$=1 \mathrm{US} \$)$. In this case, the average value of $\mathrm{R} \$ 0.17$ kilowatt-hour is considered and corresponds to the electricity tariff, off-peak, subgroup A2 (88-138 kV), charged by Minas Gerais Energy Company (CEMIG) in 2014, with no government taxes (ICMS, PIS / PASEP, COFINS and public lighting contribution).

However, it is likely that there are more holes of varying diameters in a compressed air distribution piping, which increases the additional expenditure in electricity. Thus, one can infer that the maintenance of pipes is highly rewarding, and can even prevent unnecessary replacement of a compressor with a higher capacity (Rollins, 2004). Thus, the study of the losses in the compressed air distribution system of the blast furnace plant is justified, since the compressors are not working according to the initial plan design, consuming electricity in excess. 


\section{Material and methods}

For the study, some procedures that assisted in the collection and discussion of the data must be followed. The compressed air delivery line is subjected to a visual inspection and an ultrasonic non-destructive testing, to identify waste points. Non-conforming points were identified with tags, photographed and stored.

The first data collected related to the project is carried out in the field where the operation of the equipment is analyzed. Based on the perception of non-conventional operation of the compressor, the dispensing line is subjected

\section{Discussion}

The company was established in Brazil in the early part of the twentieth century. Over the years, the company grew and added more manufacturing plants in Brazil and abroad. With a wide range of products marketed to the five continents, the group operates in the sectors of construction, industry and agriculture. This work was performed using a specific plant in this company. This plant was established in 1986 and is one of the major steelmaking industries of Brazil. Its product mix consists of billets, slabs, blooms, rolled structural shapes of parallel tabs, wire rod, and carbochemical products.

In the production system, the blast furnace of Chinese origin is responsible for the molten metal delivery, having an installed production capacity of 1.5 million tons per year. For the plant operation, compressed air is necessary to meet the demand of pneumatic tools, pneumatic cylinders, among other applications. There is a unique compressed air system to meet the demand of this plant. Thus, the compressed air system is comprised of three compressors from Atlas Copco, GA315W model with power rating of $271 \mathrm{~kW}$. Each compressor at full load is able to deliver about $2790 \mathrm{~m}^{3} / \mathrm{h}$ of compressed air with an average pressure of $0.74 \mathrm{MPa}$ for the production process.

In the initial design project, one engine should work full time, the other in charge and relief, and the last one on standby, ie only triggered in the event of temporary need. However, in reality, one engine works full time and the two others in charge and relief to meet the demand, to an ultrasound test so that waste points are measured. Ultrasonic measurement is performed by Ultraprobe ${ }^{\circledR} 10,000$ device of UE Systems. This device is the latest technology, able to perform condition analysis, record sounds, and store and manage data. In addition, through a photography camera, a record of the necessary data is made.

From the supervisory system and data acquisition, which records and stores all the data on the electromechanical equipment of the blast furnace plant, the energy consumption of compressors is obtained at any time.

increasing the power consumption of the compressed air system.

In order to quantify the wasted amounts of compressed air, an ultrasound test on the compressed air distribution line of the blast furnace was performed. In order to process the data and get reliable results, an outsourced company with extensive experience was used for tests of this nature.

The data provided by Ultraprobe ${ }^{\circledR}$ 10,000 unit of UE Systems are acoustic data in $\mathrm{dB}$ unit, and through the Compressed Gas Loss Guess-Timator software, provided by the manufacturer, these values are converted to $\mathrm{m}^{3} / \mathrm{h}$, making it possible to measure the flow of wasted air. Table 1 shows the results.

Observing Table 1, all waste points were numbered and arranged in the first column. The second and third columns refer to the location of the identified leaks. In the fourth column, the designed pressure value in the line is 100 psig. Then, in column five are the acoustic measured values (in $\mathrm{dB}$ ), and finally, in column six is shown the flow calculated by the Compressed Gas Loss Guess-Timator software (in $\mathrm{m}^{3} / \mathrm{h}$ ). Through Table 1 , one can identify thirty-seven points of leakage, which results in a rate of $475.01 \mathrm{~m}^{3} / \mathrm{h}$, confirming the potential energy gain if these are eliminated.

The values shown in Table 1 are indicative as they are specifics and these leaks may vary over time. Through the power $(271 \mathrm{~kW})$ and flow $\left(2790 \mathrm{~m}^{3} / \mathrm{h}\right)$ of the compressor, the calculated energy loss was approximately $33220 \mathrm{kWh} /$ month.

Among the points collected, the
The data provided by the ultrasound device were treated by the software Compressed Gas Loss Guess-Timator, provided by the manufacturer. Once treated, these data were arranged in the Microsoft Excel spreadsheet software, as the data obtained through the monitoring system and data acquisition, allowing the tab and their critical analysis.

After identifying the waste points, it is necessary to eliminated them. Once this step is completed, the electricity consumption before and after the elimination is compared, in order to verify the gains in terms of energy consumption. number 15 and 36, which have measuring $120 \mathrm{~dB}$, are considered the higher values, which for example are equivalent to a turbine aircraft in operation. These points do not deal with leaks, but incorrect use of compressed air. In this case, the calculated flow rate can be greater than $22.19 \mathrm{~m}^{3} / \mathrm{h}$ as shown in Table 1 , since the equipment has reached its upper limit measurement. The incorrect application of compressed air is checked because there is a hose blowing compressed air in the main loading belt of the blast furnace (C1 belt), acting as a cleaner; an activity that should be performed by a scraper. It is noteworthy that this is not a standard operating procedure error but an improper installation made for convenient operation. In this case, the measurement points were identified and performed despite the ultrasound test not being recommended because it is not a leak. The problem is recurrent in the secondary belt furnace loading (C2 belt). It is noted that the adoption of compressed air for cleaning the belts is provisional. The original scrapers broke and have not been replaced, and compressed air is being functional, but costly, since the compressed air supply is not interrupted.

Leaks in the other points collected are due to inefficient maintenance of pipe fittings, primarily cylinders, valves and filters. From Table 1, it is observed that point 6 shows the acoustic measured value of $81 \mathrm{~dB}$ which corresponds to a rate of $12.26 \mathrm{~m}^{3} / \mathrm{h}$. In this case, the valve was no longer functional and the leak has not been recognized by means of a daily inspection, only in data collection for this work. 
Table 1

Results of ultrasonic measurements and compressed air flow loss.

\begin{tabular}{|c|c|c|c|c|c|}
\hline Point & Area & Position & $\begin{array}{l}\text { Line pressure } \\
\text { (psig) }\end{array}$ & $\begin{array}{c}\text { Acoustic } \\
\text { measurement } \\
(\mathrm{dB})\end{array}$ & $\begin{array}{l}\text { Calculated volumetric } \\
\text { flowrate }\left(\mathrm{m}^{3} / \mathrm{h}\right)\end{array}$ \\
\hline 1 & Compressors room BF & Air dryer number 1 & 100 & 100 & 16.26 \\
\hline 2 & Dedusting of BF & Line filter & 100 & 97 & 15.61 \\
\hline 3 & Dedusting of BF & Air Reservoir & 100 & 62 & 8.57 \\
\hline 4 & Dedusting of BF & Valve of chamber 7 right side & 100 & 87 & 13.49 \\
\hline 5 & Dedusting of BF & Final Valve in the right side & 100 & 61 & 8.38 \\
\hline 6 & Dedusting of BF & Final Valve in the left side & 100 & 81 & 12.26 \\
\hline 7 & Dedusting of BF & Valve of chamber 7 left side & 100 & 75 & 11.06 \\
\hline 8 & Raceway area BF & Service valve & 100 & 62 & 8.57 \\
\hline 9 & Raceway area BF & Operation room of cannons 1 and 2 & 100 & 81 & 12.26 \\
\hline 10 & Raceway area BF & Refrigeration panel of the punch drill 2 & 100 & 95 & 15.18 \\
\hline 11 & Raceway area BF & Panel of the spout 4 & 100 & 63 & 8.75 \\
\hline 12 & Raceway area BF & Panel of the spout 1 & 100 & 71 & 10.28 \\
\hline 13 & Raceway area BF & Punch service valve 1 & 100 & 62 & 8.57 \\
\hline 14 & Raceway area BF & Refrigeration panel of the punch drill 1 & 100 & 100 & 16.26 \\
\hline 15 & Topo do BF & Blower of the belt C1 & 100 & 120 & 22.19 \\
\hline 16 & Regenerator of BF & Service air near stairs & 100 & 72 & 10.47 \\
\hline 17 & Pulverized coal injection of BF & Line lubricator jumper left & 100 & 100 & 16.26 \\
\hline 18 & Pulverized coal injection of BF & Line lubricator 6th floor & 100 & 77 & 11.45 \\
\hline 19 & Dedusting of BF & Pressure vessel of dedusting & 100 & 83 & 12.67 \\
\hline 20 & Dedusting of BF & Pressure vessel of dedusting & 100 & 64 & 8.94 \\
\hline 21 & Dedusting of BF & Cylinder 1 of right side & 100 & 84 & 12.87 \\
\hline 22 & Dedusting of BF & Gauge of the camera 1 on the right & 100 & 95 & 15.18 \\
\hline 23 & Dedusting of BF & Cylinder 1 of left side & 100 & 94 & 14.97 \\
\hline 24 & Dedusting of BF & Cylinder 2 of right side & 100 & 81 & 12.26 \\
\hline 25 & Dedusting of BF & Cylinder 2 of left side & 100 & 64 & 8.94 \\
\hline 26 & Dedusting of BF & Cylinder 3 of left side & 100 & 84 & 12.87 \\
\hline 27 & Dedusting of BF & Cylinder 4 of right side & 100 & 81 & 12.26 \\
\hline 28 & Dedusting of BF & Cylinder 4 of left side & 100 & 76 & 11.26 \\
\hline 29 & Dedusting of BF & Cylinder 5 of left side & 100 & 91 & 14.33 \\
\hline 30 & Dedusting of BF & Cylinder 6 of right side & 100 & 73 & 10.66 \\
\hline 31 & Dedusting of BF & Cylinder 6 of right side & 100 & 81 & 12.26 \\
\hline 32 & Dedusting of BF & Cylinder 7 of right side & 100 & 101 & 16.48 \\
\hline 33 & Dedusting of BF & Cylinder 8 of right side & 100 & 101 & 16.48 \\
\hline 34 & Dedusting of BF & Cylinder 6 of left side & 100 & 89 & 13.91 \\
\hline 35 & Loading BF & Activation of the TC C2 & 100 & 79 & 11.86 \\
\hline 36 & Loading BF & Blower of the belt TC C2 & 100 & 120 & 22.19 \\
\hline 37 & Dedusting of BF & Line Filter & 100 & 63 & 8.75 \\
\hline \multicolumn{5}{|c|}{ TOTAL OF LEAKS } & 475.01 \\
\hline
\end{tabular}

Another common source of leaks are line filters. Line filters have a useful life determined by the manufacturer and must be strictly replaced. If this procedure is not done, it can decrease the flow rate and/or air pressure, and may even stop the line. Therefore, by the data presented in this section, the large number of losses in the compressed air distribution is confirmed. The elimination of these points can save 475.01 $\mathrm{m}^{3} / \mathrm{h}$ of compressed air, which may have 
greater savings considering the observations related to the points 15 and 36 .

In order to solve the problems related to compressed air distribution waste in the blast furnace plant, an action plan was proposed. It is suggested that leakage points should be minimized and changes made related to the cleaning of loading belts.

First of all, the elimination of leakage points consists of corrective actions. However, the loading belts of the blast furnace cannot be without cleaning, so

Figure 1

Belt Scraper of the C1 area:

(a) design and (b) installed

Despite the improvements made, it is necessary that they remain so leaks are non-recurring. Therefore, the future implementation of an inspection plan in the compressed air distribution of the blast furnace plant is required. It was found that the identified problems are arising from the absence of more detailed standard operating procedures and directed activities and responsibilities.

Table 2

Monitoring the energy consumption of blast furnace compressors before elimination of waste points. compressed air was not eliminated immediately. Although this is costly and not ideal, the compressed air performs the function of keeping the belt clean. Thus, a permanent solution is needed before the elimination of the compressed air hoses.

In the blast furnace project, scrapers for cleaning the belts were projected. This equipment is indicated by companies that work in the area of the belt conveyor. So, scrapers have been specified for elimination of the use of compressed air. The C1 belt scraper project, related

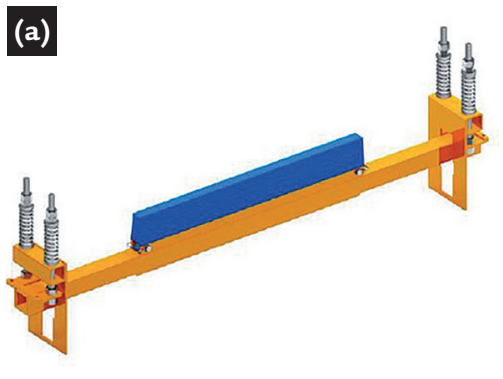

Design of the belt scraper

After the implementations, the electricity consumption of the compressors was monitored. Through the supervision system and data acquisition available in the blast furnace plant, the energy consumption of compressors was obtained over a defined period.

Table 2 shows the electricity consumption of the three compressors from September 2012 to September 2013 as to the point 15 is shown in Figure 1a. It is a polyurethane blade able to clean effectively in extreme environments. The cleaning of the belts is important to prevent material accumulation that can adhere to rollers and other accessories, shortening the life of the assembly and keeping the environment clean. The scraper installed is displayed in Figure $1 \mathrm{~b}$.

It is noted in Figure $1 \mathrm{~b}$ that the compressed air hose has been eliminated and the scraper performs the cleaning function correctly.

(b)

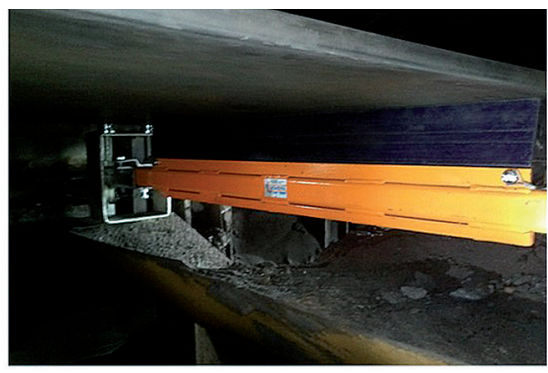

Belt scraper installed

well as the total cost spent in electricity of the air compressed system. These data refer to the period prior to the elimination of waste points in compressed air system. Table 2 shows that the average electricity consumption of the compressors between September 2012 and September 2013 was $32,785.42 \mathrm{kWh}$, which corresponds to an average monthly cost of $\mathrm{R} \$ 52,259.38$.

\begin{tabular}{c|c|c|c} 
Month & $\begin{array}{c}\text { Global electricity consumption } \\
\text { of compressors }(\mathrm{kWh})\end{array}$ & $\begin{array}{c}\text { Average cost of kilowatt- } \\
\text { hour for the power plant }\end{array}$ & $\begin{array}{c}\text { Total cost } \\
\text { spend in electricity }\end{array}$ \\
\hline Sep/2012 & 345574.04 & $\mathrm{R} \$ 0.17$ & $\mathrm{R} \$ 58,747.59$ \\
\hline Oct/2012 & 347501.71 & $\mathrm{R} \$ 0.17$ & $\mathrm{R} \$ 59,075.29$ \\
\hline Nov/2012 & 343234.70 & $\mathrm{R} \$ 0.20$ & $\mathrm{R} \$ 68,646.94$ \\
\hline Dec/2012 & 358553.03 & $\mathrm{R} \$ 0.18$ & $\mathrm{R} \$ 64,539.55$ \\
\hline Jan/2013 & 362625.60 & $\mathrm{R} \$ 0.17$ & $\mathrm{R} \$ 61,646.35$ \\
\hline Feb/2013 & 321021.12 & $\mathrm{R} \$ 0.15$ & $\mathrm{R} \$ 48,153.17$ \\
\hline Mar/2013 & 338006.64 & $\mathrm{R} \$ 0.18$ & $\mathrm{R} \$ 60,841.20$ \\
\hline Apr/2013 & 275169.60 & $\mathrm{R} \$ 0.15$ & $\mathrm{R} \$ 41,275.44$ \\
\hline May/2013 & 306282.48 & $\mathrm{R} \$ 0.16$ & $\mathrm{R} \$ 49,005.20$ \\
\hline Jun/2013 & 319464.00 & $\mathrm{R} \$ 0.13$ & $\mathrm{R} \$ 41,530.32$ \\
\hline Jul/2013 & 319570.32 & $\mathrm{R} \$ 0.13$ & $\mathrm{R} \$ 41,544.14$ \\
\hline Aug/2013 & 309504.00 & $\mathrm{R} \$ 0.13$ & $\mathrm{R} \$ 40,235.52$ \\
\hline Sep/2013 & 315223.20 & $\mathrm{R} \$ 0.14$ & $\mathrm{R} \$ 44,131.25$ \\
\hline Average & 327825.42 & - & $\mathrm{R} \$ 52,259.38$ \\
\hline
\end{tabular}


After performing the improvements, the compressors electricity

\begin{tabular}{c|c|c|c} 
Month & $\begin{array}{c}\text { Global electricity consumption } \\
\text { of compressors }(\mathrm{kWh})\end{array}$ & $\begin{array}{c}\text { Average cost of kilowatt- } \\
\text { hour for the power plant }\end{array}$ & $\begin{array}{c}\text { Total cost s } \\
\text { pend in electricity }\end{array}$ \\
\hline October 2013 & $129,701.52$ & $\mathrm{R} \$ 0.12$ & $\mathrm{R} \$ 15,564.18$ \\
\hline November 2013 & $134,388.00$ & $\mathrm{R} \$ 0.13$ & $\mathrm{R} \$ 17,470.44$ \\
\hline December 2013 & $180,561.36$ & $\mathrm{R} \$ 0.12$ & $\mathrm{R} \$ 21,667.36$ \\
\hline January 2014 & $136,695.12$ & $\mathrm{R} \$ 0.13$ & $\mathrm{R} \$ 17,770.37$ \\
\hline February 2014 & $120,274.56$ & $\mathrm{R} \$ 0.14$ & $\mathrm{R} \$ 16,838.44$ \\
\hline Average & $140,324.10$ & - & $\mathrm{R} \$ 17,862.16$ \\
\hline
\end{tabular}

Table 3 shows that from October 2013, the drop in electricity consumption was drastic due to the elimination of the air compressed system's leakage points.

Note that the average consumption of the three compressors fell from $327,825.42$ to $140,324.11 \mathrm{kWh}$ per month, which means a reduction of $57.2 \%$ in energy consumption. Consequently, it was possible to return a compressor to stand-by condition, according

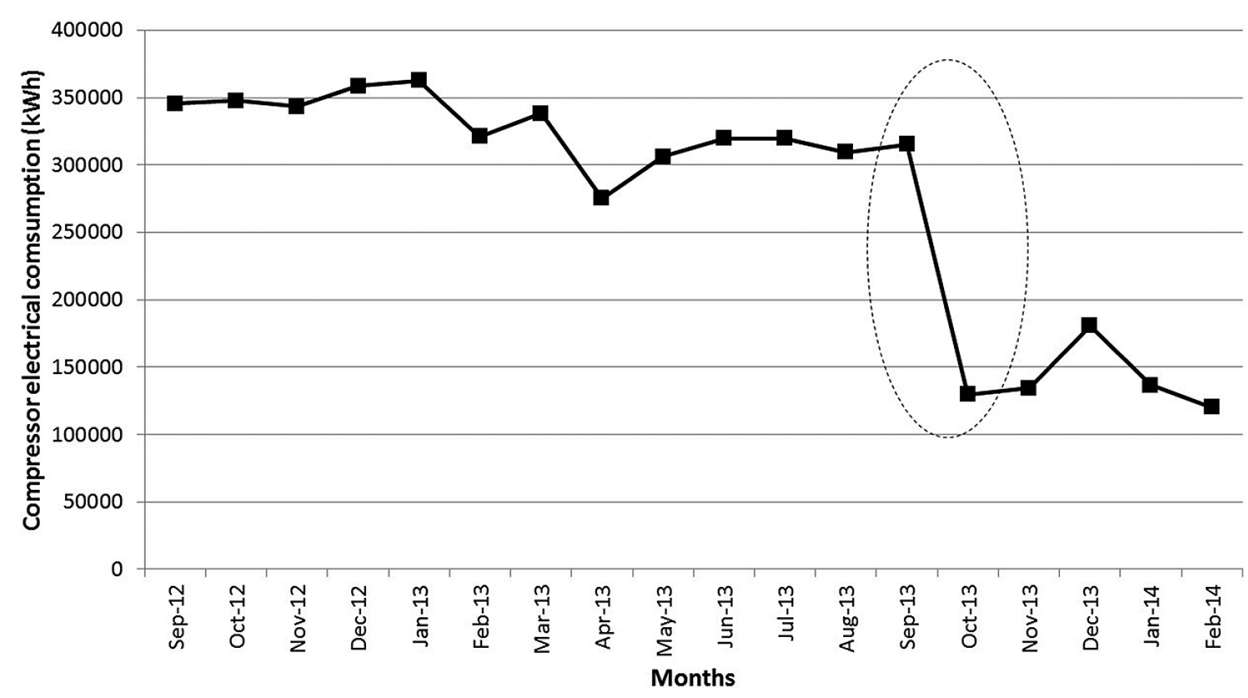

Figure 2 displays that the electricity consumption decreased about 185,000 kW between September 2013 and October 2013, which corresponds

to $57.2 \%$ of electricity consumption reduction. The decrease in costs because of the elimination of waste points, mainly by the installation of scrapers system was monitored and reported in Table 3.

Table 3

Monitoring of electricity consumption of blast furnace compressors after the elimination of air compressed system waste points.

and the actual reduction in consumption is due to the fact that the tests only detect leaks, and the flowrate calculated in cleaning the $\mathrm{C} 1$ and $\mathrm{C} 2$ belts were below the real value and thus do not provide the correct compressed air leakage. The drop in electricity consumption is also displayed in Figure 2. In this figure, it is evident that the decrease in electricity consumption occurs in the month of October 2013.

Figure 2

Electricity consumption of blast furnace compressors.

in the belts, was around $\mathrm{R} \$ 15,000.00$. This study proves the feasibility of eliminating the compressed air system waste points.

\section{Conclusions}

Compressed air is typically one of the most expensive utilities in an industrial facility. Based on energy assessment of mid-sized industries, compressed air typically comprises from about $5 \%$ to $20 \%$ of a plant's annual electric costs (Schmidt and Kissock, 2015). In this paper, it was found that there was no effective stan- dard operating procedure for inspection and maintenance of the compressed air system of a company, and through an ultrasonic test, it was found that leaks were responsible for the high electric energy consumption of the compressors. Thus, the elimination of these leaks was made in order to solve the problem, the elimination of compressed air waste points generated an average monthly reduction of about $185,000 \mathrm{kWh}$ or $57.2 \%$ in electricity consumed by the compressors, which is equivalent to the consumption of a compressor Atlas Copco GA315W. Therefore, it was possible to return a machine to stand-by condition. However, to keep the optimal 
functioning of the compressed air system and a non-recurring problem, it becomes necessary to create a more detailed standard operating procedure and directed activities and responsibilities. The work

\section{Acknowledgments}

The authors acknowledge the Brazilian Federal University of Ouro Preto

\section{References}

on the energy consumption reduction of the blast furnace of a steelmaking process compressors is of main importance for the understanding of how the bad use of compressed air has a negative impact on the consumption of electric energy. In this sense, additional studies were proposed to further reduce the energy consumption of compressors and, jointly, increase their availability.
(UFOP) and those who helped in the execution of this project.
ALYRIO, R. D. Metodologia científica. Rio de Janeiro: PPGEN - UFRRJ. 2008. (In Portuguese).

ATLAS COPCO. Manual do ar comprimido. São Paulo: McGraw-Hill do Brasil. 1976. (In Portuguese).

CALENTE, A., PIO, A., MENEZES, R. T. Técnicas preditivas ligadas à inspeção. Serra: CST - Arcelor Brasil. 2014. CEMIG 2014. Available at <http://www.cemig.com.br/ptbr/atendimento/ Paginas/valores_de_ tarifa_e_servicos.aspx>. Accessed on January 2014. In Portuguese.

CRESWELL, J. Qualitative inquiry and research design: choosing among five traditions. Thousand Oaks. CA: SagePublications, 1998.

DICIONÁRIO MICHAELIS ONLINE. Available at <http://michaelis.uol. com.br/moderno/portugues/>. Accessed on December 2013.

FERRARI. A. T. Metodologia da pesquisa científica. São Paulo: McGraw-Hill do Brasil, 1982. (In Portuguese).

FIALHO, A. B. Automação pneumática. São Paulo: Editora Érica LTDA, 2007. (In Portuguese).

SCHMIDT, C., KISSOCK, K. Power characteristics of industrial air compressors. Available at https://www.udayton.edu/engineering/centers/industrial_assessment/resources/docs/pdf/Power CharAirComp_IETC2003. pdf. Accessed on June 2015.

FIDELIS, Jocelito. Estudo de eficiência energética em instalações de ar comprimido. São Leopoldo: Universidade Federal do Vale dos Sinos, 2011. 76 p. (In Portuguese - Trabalho de Conclusão de Curso - Graduação em Engenharia Mecânica).

GARCIA, A., SPIM, J. A., SANTOS, C. A. Ensaio dos materiais. Rio de Janeiro: Livros Técnicos e Científicos, 2008. (In Portuguese).

GERhardT, T. E., SIlveIRA, D. T. Métodos de Pesquisa. Porto Alegre: Editora UFRGS, 2009. (In Portuguese).

DIAS JÚNIOR, Jair, PEIXOTO, Eliezer. Eficiência energética em sistema de ar comprimido - recuperação do calor de compressão. Bahia: Instituto Federal de Educação, Ciência e Tecnologia da Bahia, 2010. 31 p. (Trabalho de conclusão de curso - Graduação em Engenharia Industrial - In Portuguese).

LAKATOS. E. M., MARCONI. M. A. Fundamentos de metodologia científica. (7 ed.) São Paulo: Atlas, 2010. (In Portuguese).

MACINTYRE. A. J. Instalações hidráulicas. Rio de Janeiro: Livros Técnicos e Científicos, 1996. (In Portuguese).

PARKER AUTOMATION. Dimensionamento de redes de ar comprimido. São Paulo: 2006. (In Portuguese).

RADUENZ, S. L., DESCHAMPS, E., PÉRES, A. Análise de conservação de energia elétrica nas indústrias do setor metal-mecânico do Alto Vale do Itajaí. Revista E-Tech: Tecnologias para competitividade industrial, Florianópolis, v. 2, n. 1, p. 1-15, $1^{\circ}$ Sem., 2009. (In Portuguese).

RICHARDSON, R. J. Pesquisa social: métodos e técnicas. São Paulo: Editora Atlas, 1989. (In Portuguese).

ROCHA, C. R., MONTEIRO, M. A. G. Eficiência energética em sistemas de ar comprimido - manual prático. Rio de Janeiro: Eletrobrás; Procel, 2005. (In Portuguese). 
ROLLINS, J. P. Manual de ar comprimido e gases. São Paulo: Prentice Hall, 2004.

SANTOS. A. H. M. et al. Conservação de energia - eficiência energética de equipamentos e instalações. Itajubá: FUPAI, 2006. (In Portuguese.)

XENOS, Harilaus G. Gerenciando a manutenção produtiva. Belo Horizonte: Editora EGD, 2004. (In Portuguese).

Received: 7 January 2016 - Accepted: 3 June 2016. 